\title{
2. $\mathrm{A} / \mathrm{D}, \mathrm{D} / \mathrm{A}$ コンバータ
}

松 沢

昭 ${ }^{\dagger}$

\section{1. ま え がき}

近年, ディジタルテレビやディジタル VTRなど, 従来のテレビやVTRの信号処理をディジタル化した ものや, HDTV, EDTV, IDTVのようにディジタ ル技術を全面的に活用して構成された新しい映像機器 が検討され，一部実用化されている。これらの背景と して, メモリーとともにビデオ信号用の $\mathrm{A} / \mathrm{D}, \mathrm{D} / \mathrm{A}$ コンバータの低価格化, 高性能化があるのはいうまで もない.

本稿では, これらビデオ信号用の $\mathrm{A} / \mathrm{D}, \mathrm{D} / \mathrm{A}$ コン バータの技術動向について紹介する。

\section{A/D， D/A コンバータの性能と用途}

変換速度が数 $\mathrm{M}$ サンプル/s を越え 4 〜 10 ビット の分解能を有する $\mathrm{A} / \mathrm{D}, \mathrm{D} / \mathrm{A}$ 変換器は多数開発され

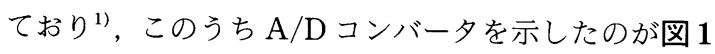

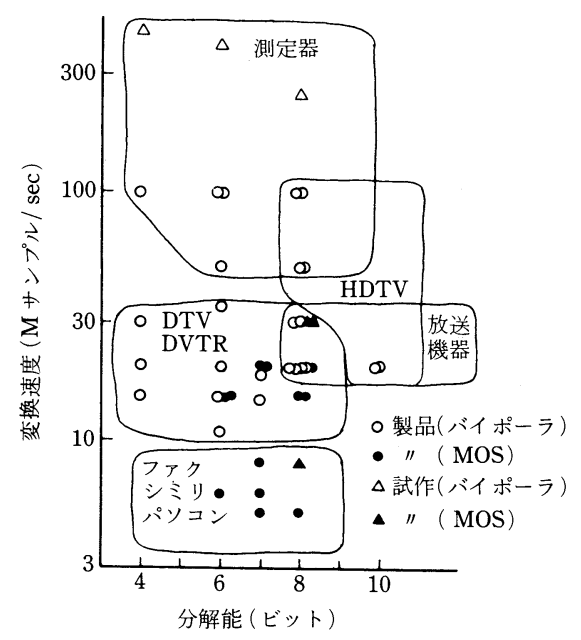

図 1 A/D コンバータの性能と用途

†松下電器産業株式会社 半導体研究センター

“2. A/D, D/A Converter” by Akira Matsuzawa (Semiconductor Research Center, Matsushita Electric Industrial Co., Ltd., Osaka)

1176 (6)
である.図からわかるように，10〜30 M サンプル/ $\mathrm{s}$ が中心となっている.これらはディジタルテレビ, VTR 等に多く用いられており, 分解能 6〜8 8゙ット のものが中心となっている.この分野ではバイポーラ タイプとMOSタイプが混在し，しのぎを削ってい る.これより変換速度が低い方はMOSタイプが, 高 い方はバイポーラタイプで占められている。

放送機器は変換速度 $10 \sim 30 \mathrm{M}$ サンプル $/ \mathrm{s}$ で分解能 8〜10 ビット ${ }^{23)}$ のものが用いられている.

HDTV 用としては分解能 8 ビットで変換速度 $50 \mathrm{M}$ サンプル/s 以上のものが4)5) が用いられているが, 帯 域圧縮信号を扱うものは変換速度が $20 \mathrm{M} \sim 35 \mathrm{M}$ サン プル $/ \mathrm{s}$ 程度で良いので, 10 ビット分解能の $\mathrm{A} / \mathrm{D}$ 変 換器に高性能標本化回路を付加して用いることもあ る.

変換速度が $50 \mathrm{MHz}$ を越えるものは測定器等に用 いられることが多く, 8 ビットで $250 \mathrm{M}$ サンプル $/ \mathrm{s}$ のもの ${ }^{6)}$ が試作されている.

変換速度 $10 \mathrm{M}$ サンプル/s 以下のものはファクシミ リ，パソコン等のイメージ入力デバイスとして用いら れることが多い。

$\mathrm{D} / \mathrm{A}$ 変換器については図示しなかったが, $\mathrm{A} / \mathrm{D}$ 変 換器よりも容易に高速, 高精度化が可能なため, 分解 能については 10 ビットのものもかなり多く, 高精細 度ディスプレイの普及につれて, 変換速度も $100 \mathrm{M}$ サンプル/s 以上のものも珍しくなくなってきており, $500 \mathrm{M}$ サンプル/sのもの $/ \mathrm{s}$ も試作されている.

\section{3. ビデオ用 $\mathrm{A} / \mathrm{D}$ コンバータ}

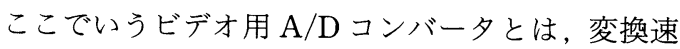
度 $10 \mathrm{M} \sim 30 \mathrm{M}$ サンプル/s の A/D コンバータをさ している.このうち分解能 8 ビットのものが中核を成 し, 技術的発表も多く，またよく利用されている。

図 2 はこのビデオ用 8 ビット A/D コンバータの消 費電力とチップサイズを示している．A/D ンンバー 夕の性能としては直線性とか $S / N, \mathrm{DG}, \mathrm{DP}$ など多 テレビジョン学会誌 Vol. 40, No. 12 (1986) 




図 2 ビデオ用 $\mathrm{A} / \mathrm{D}$ コンバータの性能推移

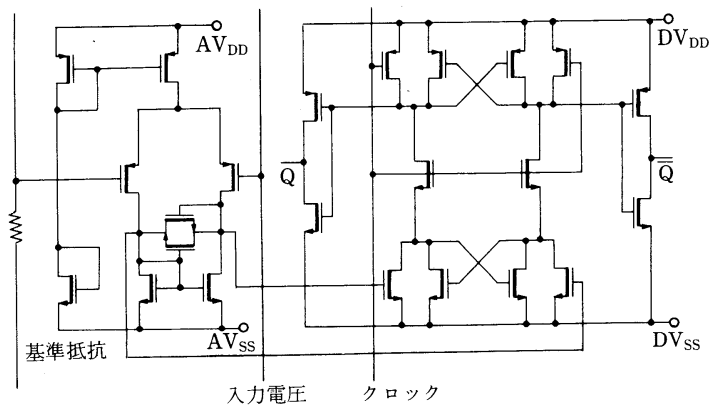

図 3 MOS 差動比較器

くの評価項目があるが1)3), 利用上の大きな要素はコ ストと消費電力であろう．このうちコストは技術以外 の様々な要素がからみ, 明確なとらえ方はできないの で, チップサイズを目安として示している.

消費電力やチップサイズは毎年確実に低下してお り,この 7 年間で消費電力は約 $1 / 10$ になっている. チップサイズは約 $1 / 5$ になっている.

1985 年以降は MOS タイプのものが多くなってき ており, 低電力化, 低コス卜化に寄与しているが, バ イポーラタイプのものも消費電力では MOS タイプと 同等のものが開発されており ${ }^{8)}$, 一概にMOSである から低電力であるとは決めつけられない.

しかしながら今後, A/D, D/A コンバータは他の ロジックやメモリー系と混在してオンチップ化が図ら れる方向にあるので, この点から MOS の技術は重要 である。

以下に, 最近開発された MOS タイプの A/D コン バー夕のうち特徵的なものを数件紹介する.

\section{1 差動比較器を用いた並列型 $\mathrm{A} / \mathrm{D}$ コンバータ}

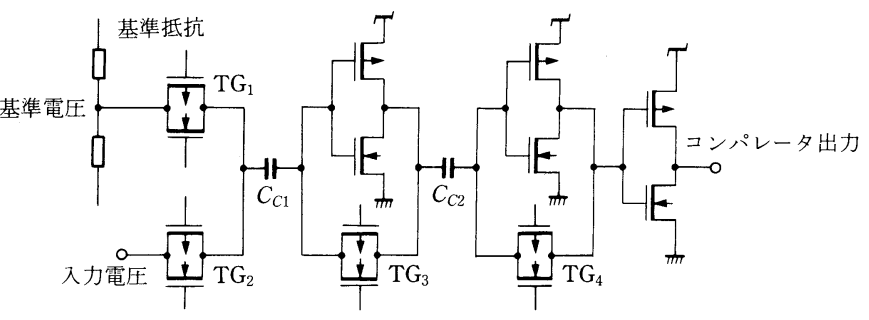

図 4 MOS チョッパ比較器

MOSタイプであっても, バイポーラタイプと同様 に差動比較器を用いて並列型 $\mathrm{A} / \mathrm{D}$ 変換器を実現する ことができる ${ }^{9)}$. 図 3 に用いられた比較器の回路を示 す.

従来 MOS タイプは閾值電圧変動が大きく, 高精度 の差動比較器の実現は難しいと見られていたが, 現在 のプロセス技術をもってすれば分解能 8 ビット精度ぐ らいまでは実現できる.

チップ全体の消費電力が変換速度 $20 \mathrm{MHz}$ で 450 $\mathrm{mW}$, チップサイズが $4.92 \times 6.2 \mathrm{~mm}$ と MOS タイフ にしては大きいが, 後述のチョッパ比較器を用いたも のよりも, クロックパルスが入力部に漏れる, キック バックが小さく，扱い易いという特長がある.

この回路形式において, さらに低電力化, 低コス卜 化を進めるためには, トランジス夕の短チャンネル化 を進めなければならないが, チャンネル長 $5 \mu \mathrm{m}$ 以下 ではオフセット電圧のばらつきが急激に上昇するとい う報告 ${ }^{10)}$ があり，これ以上の短チャンネル化は困難で あるといえる。

\section{2 チョッパ比較器を用いた並列型 $\mathrm{A} / \mathrm{D}$ コンバ -夕}

$\operatorname{MOS}$ で比較器を構成する場合, 先に述べた差動型 はオフセット電圧のばらつきが大きく, この欠点を克 服するためにチョッパ比較器11 が開発された。

チョッパ比較器を図 4 に示す．この回路の動作はク ロックパルスに同期して行われ，クロックの位相によ り参照モードと比較モードの 2 つのモードを有する． 参照モードのときはトランスファゲート $\mathrm{TG}_{1}, \mathrm{TG}_{3}$, $\mathrm{TG}_{4}$ が閉じられ， $\mathrm{TG}_{2}$ は開かれる．インバータの入 出力が $\mathrm{TG}_{3}, \mathrm{TG}_{4}$ で閉じられることにより, インバ ータの入力電圧はインバータの閾值電圧に設定され る.このとき $\mathrm{TG}_{1}$ により基準電圧が入力部のコンデ ンサ $C_{c 1}$ に印加され, コンデンサ $C_{c 1}$ にはインバー夕 の閾値電圧と基準電圧との間の電位差が保持される.

次に比較モードになると $\mathrm{TG}_{2}$ が閉じられ, $\mathrm{TG}_{1}$, $\mathrm{TG}_{3}, \mathrm{TG}_{4}$ が開かれる. $\mathrm{TG}_{2}$ が閉じられ, 入力電圧 
はコンデンサに保持されたバイアス電圧分だけシフト して, $C_{c 1}$ インバータの入力に加わり, 基準電圧を閾 値電圧として比較増幅される。

この回路ではインバー夕の閾值電圧のばらつきは自 動的にキャンセルされることになり，MOS 回路の欠 点をうまく取り除いている。しかしながら, 高速のク ロックでアナログ部のトランスファゲートを開閉する ため, クロックパルスからの電荷の流れ入みによるク ロックフィードスルーがあり, オフセット電圧を発生 させる。

また, $\mathrm{TG}_{1}, \mathrm{TG}_{2}$ 等により入力端や基準抵抗端にク ロックパルスがそのまま漏れ, 基準電圧が変動し, 直 線性が劣化するなどの課題も多い。しかしながら，各 トランスファゲートを動作させるクロックのタイミン グをずらすことや，トランジスタの微細化などの工夫 により分解能 9 ビット程度の精度の見通しがついてい $3^{12)}$.



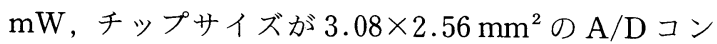
バータ13)が試作されている。

\section{3 直並列型 ( 2 ステップパラレル) $\mathrm{A} / \mathrm{D}$ コンバー 夕}

今まで述べた並列型の他に, より低電力, 低コスト を目ざして直並列構成の $\mathrm{A} / \mathrm{D}$ コンバータ ${ }^{14)}$ が試作さ れている. 図 5 がその構成であるが, 動作は標本化回 路により標本化され，一定時間保持された入力信号に 対し, 初めに第 1 の 16 個の比較器により第 1 の並列 型の $\mathrm{A} / \mathrm{D}$ 変換を行い, 上位ビットの出力值を決定 し, 次に第 1 の変換で得られた值に対応した一部の区 間の基準電圧を選択的に第 2 の 15 個の比較器の基準

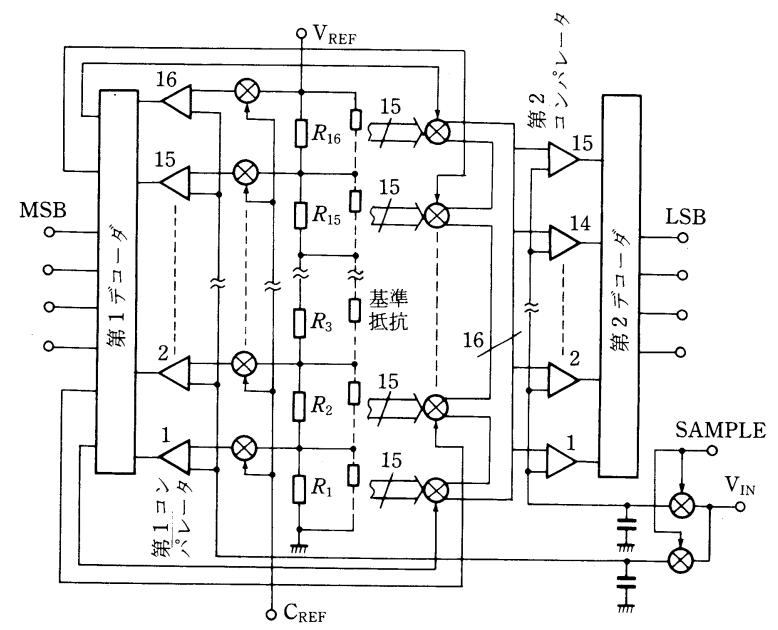

図 5 直並列型（2ステップパラレル） A/D コンバータ
電圧として発生し，入力信号と比較することにより下 位ビットの出力值を決定するものである.

このため基準抵抗をメッシュ状に配し，MOSトラ ンスファゲートによりタップ切換えを行っている.

この方式においては比較器が約 $1 / 8$ になり, 大幅に 素子数や消費電力が減少するという特長を有する. 欠 点としては, 2 回の変換動作を必要とするために, 速 度が半減することである。このため, 消費電力は 20 $\mathrm{mW}$ と従来に比べ大幅な低電力化が図られているが, 変換速度は $5 \mathrm{M}$ サンプル/sec と低い.

\section{4. 超高速 $\mathrm{A} / \mathrm{D}$ コンバータ}

変換速度が $100 \mathrm{M}$ サンプル/s を越える超高速 $\mathrm{A} /$ D コンバータはバイポーラタイプである.MOSトラ ンジスタのオフセット電圧の変化が, 寸法の変化に対 してほほ比例関係になるのに対し, バイポーラトラン ジス夕の場合は対数比例関係になることや，同一の大 きさの場合は MOS トランジスタょりも電流駆動能力 が大きくなるので, コレクタ領域などの寄生容量を低 減すれば, MOSトランジス夕よりも高分解能で高速 な A/D コンバータが得られる.また, MOSトラン ジスタを用いたものと同等の低消費電力 $\mathrm{A} / \mathrm{D}$ コンバ ータが得られており ${ }^{8)}$, デバイスの改良により,さら に低電力化を図ることができるものと思われる．

ところで, このようなバイポーラトランジスタの特 長を生かして超高速 A/D コンバー夕45)15) が開発され ているが, 映像用として注目すべきは, 高い変換速度 とともに，広い入力帯域ではなかろうか．

現在のところ同一の変換速度の A/D コンバータで も, ダイナミック特性はかなりのばらつきがあり, 使 用に当っては注意が必要である。例えばダイナミック 特性のひとつを表す $S / N$ において超高速 $\mathrm{A} / \mathrm{D}$ コンバ ータのそれは通常のビデオ用 $\mathrm{A} / \mathrm{D}$ コンバータに比べ



図 6 変換特性比較 
てはるかに良好な特性を示す。

図 6 に変換速度 $30 \mathrm{M}$ サンプル $/ \mathrm{s}$ 程度のビデオ用 $\mathrm{A} / \mathrm{D}$ コンバータと $100 \mathrm{M}$ サンプル/s の超高速 $\mathrm{A} /$ $\mathrm{D}$ コンバータの入力周波数に対する $S / N$ を示す. ビ デオ用 $\mathrm{A} / \mathrm{D}$ コンバータ (このクラスでは比較的優秀 なものである) が入力周波数 $10 \mathrm{MHz}$ に対し, 分解能 1 ビット分に相当する $6 \mathrm{~dB}$ の劣化があるのに対し, 超高速 $\mathrm{A} / \mathrm{D}$ コンバータのそれは $30 \mathrm{MHz}$ においても $2 \sim 3 \mathrm{~dB}$ の劣化にとどまり, 極めて優秀な特性を示 す.

このため超高速 A/D コンバータは信号帯域 25 $\mathrm{MHz}$, 変換速度 $50 \sim 70 \mathrm{M}$ サンプル/s の HDTV の原信号の変換のみならず, 信号帯域は $8 \mathrm{MHz}$, 変 換速度が $16 \mathrm{MHz}$ 程度の MUSE 等の帯域圧縮された HDTV 信号に対する変換に用いられている。これは 帯域圧縮された HDTV 信号に対しては帯域内で殆ん ど劣化のない変換を要求しており, 通常のビデオ用 $\mathrm{A} / \mathrm{D}$ コンバータの特性では不充分であるためと思わ れる。

この超高速 $\mathrm{A} / \mathrm{D}$ コンバータは 24000 素子を有し, バイポーラ VLSI 技術を用いて製造される ${ }^{4) 15)}$.

\section{5. ビデオ用 $\mathrm{D} / \mathrm{A}$ コンバータ}

D/A コンバー夕は通常, 量子化された電流を, 入 カデータに応じてスイッチングして出力するだけなの で, 基本的には MOS タイプもバイポーラタイプも同 等の消費電力になる.

また, 精度も分解能 8 ビット程度まではトリミング なしに容易に実現できる、しかしながら，高速性では



図 7 MOS D/A コンバータ
バイポーラタイプが有利であり, 従来はバイポーラ夕 イプがほとんどであった.

けれども, オンチップ化のためにMOSタイプの D/A コンバータも開発され始め, 最近はHDTVに も使用可能な変換速度 $80 \mathrm{M}$ サンプル/s のものも開発 されている ${ }^{16)}$. その構成を図 7 に示す.

MOS タイプの場合, $g_{m}$ が低いため電流源を分散さ せたものが実現し易いが，さらに電流源セルをマトリ ックス状に配置し，セルにおいてマトリックスの行と 列との間の論理をとって電流源をスイッチングしてい る.

また，このように多数のセルを配置した場合，グラ ウンド線の持つ配線抵抗と流れる電流により電位分布 を有し, セルの位置により電流值が変化し, 直線性が 劣化する.このため電流源の出力する順序を中央位置 から交互に出力する方法により, 従来のように端から 順番に出力する場合に比べ直線性誤差を約 $1 / 3$ にして いる。

その他, このコンバータはデコード回路の高速化や $2.5 \mu \mathrm{m}$ のゲート長のトランジスタの採用により, 変 換速度 $80 \mathrm{M}$ サンプル/s の高速変換を実現してい る。

\section{6.むす び}

最近のビデオ信号用 $\mathrm{A} / \mathrm{D}, \mathrm{D} / \mathrm{A}$ コンバータの技術 動向について簡単に述べた. 回路技術およびプロセ ス・デバイス技術の進歩により, 年々確実に性能向上 が図られているが, この流れはコストダウンの流れも 含め, 市場の拡大につれてますます加速されるものと 思われる。

ただ, 周辺回路を含めたトータルの性能比較, 特性 評価法の標準化や変換特性と画質の関係の研究が不充 分なため, アナログ系とディジタル系のインタフェー スを司る $\mathrm{A} / \mathrm{D}, \mathrm{D} / \mathrm{A}$ コンバータを不可解なものにし ている面もあり, これらの研究や評価法の標準化の推 進も製品開発と併せて必要な時期に来ている.

(昭和 61 年 8 月 4 日受付)

\section{〔参 考 文 献〕}

1）松永, 岡部：“画像処理の普及をにらみ開発熱高まるビデオ 信号用高速 A-D 変換器 IC”, 日経エレクトロニクス, 338, pp. 137-155 (Mar., 1984)

2) T. Takemoto, et al.: "A Fully Parallel 10-bit A/D Converter with Video Speed”, IEEE J., SC-17, 6, pp. 1133-1138 (Dec., 1982)

3）松沢ほか: “ビデオ用高速 A/D コンバータ”, National Tech. Rept., 29, 2, pp. 196-207 (Apr., 1983)

4) M. Inoue, et al. : "A Monolithic 8-bit A/D Converter with $120 \mathrm{MHz}$ Conversion Rate", IEEE J., SC-19, 6, pp. 837-841 
(Dec., 1984)

5) Y. Yoshii, et al. : "An 8 bit, $100 \mathrm{~ms} / \mathrm{s}$ Flash ADC", IEEE J., SC-19, 6, pp. 842-846 (Dec., 1984)

6) B. Peetz, et al. : "An 8 b $250 \mathrm{MHz}$ A/D Converter", IEEE, ISSCC, Digest of Technical Papers, pp. 136-137 (Feb., 1986)

7) K. Maio, et al.: "A $500-\mathrm{MHz}$ 8-Bit D/A Converter", IEEE J., SC-20, 6, pp. 1133-1137 (Dec., 1985)

8) M. Hotta, et al. : "A 150-mW 8-Bit Video-Frequency A/ D Converter”, IEE J., SC-21, 2, pp. 318-323 (Apr., 1986)

9) T. Ogawara, et al. : "A High-Speed CMOS 8-bit Flash A/D Converter”, NEC Res. \& Develop., 78, pp. 91-96 (July, 1985)

10）四柳ほか：“コンパレータのオフセット電圧の評価”, 昭 61 信学総合全大, 2, p. 214 (1986)
11) T. Tsukada : CMOS 8 b $25 \mathrm{MHz}$ Flash ADC", IEEE, ISSCC, Digest of Technical Papers, pp. 34-35 (Feb., 1985)

12) 中谷裕一ほか: “低オフセット電圧サンプル・ホールド形 MOS コンパレータ”, 昭 60 信学総合全大, 2, p. 162 (1985)

13）熊本敏夫ほか：“8-bit $30 \mathrm{MHz}$ CMOS A/D コンバー夕”, 昭 61 信学総合全大, 2, pp. 194 (1986)

14) A. G. F. Dingwall : "An 8-MHz CMOS Subranging 8-Bit A/D Converter", IEEE J., SC-20, 6, pp. 1138-1143 (Dec., 1985)

15）松沢ほか：“超高速 8 ビットA/D 変換器”, National Tech. Rept., 32, 1, pp. 99-105 (Feb., 1986)

16) M. Miki, et al. : "An $80 \mathrm{MHz} 8 \mathrm{~b}$ CMOS D/A Converter", IEEE, ISSCC, Digest of Technical Papers, pp. 132-133 (Feb., 1986)

\section{新刊圈書 \\ 画像工学ハンドブック \\ 樋渡涓二 編集}

本学会誌の副題に「放送技術と画像エレクトロニク ス」とあるが, この後半の画像工学に関するハンドブ ックが出版された。これからの社会は映像化社会であ ると言われて久しいが, 最近の電波新聞等を見ても八 イビジョンを始め, 立体テレビの発売, EDTV, 衛 星放送, 映像情報ライブラリー, 電子図書館, 家庭用 VTRやビデオディスクの普及, ビデオテックスや文 字放送の実用化, 通信系ファクシミリの急激な普及と ファクシミリ放送の審議, テレビ会議や静止画伝送, 電子スチルカメラ, 8 ミリビデオ, テレビゲーム, パ ソコン通信, 追記型光磁気ディスクなど, 思いつくま まに書いても枚挙にいとまがない.

これら画像は一瞬にして多量の情報を受容でき，ま た, 訴求効果上からも情報伝達には欠かせない最も重 要な手段である.

本書の内容は 10 章からなり，1章の画像工学概論 では取扱うべき技術的分野を判り易く概説し，2 章の 視覚と画像品質では, 視覚心理や各種の視覚特性を豊 富なデー夕を用いて解説している．3 章の映像信号の 発生では, 各種撮像管や撮像板の他に, ファクシミリ やコンピュータ入力用画像発生装置など, 最近の進歩 の著しい分野にも及んでいる.4章の画像信号の符号 化では, ディジタル伝送に係わる冗長度削減やテレビ 会議などの低ビットレート伝送も解説しており，5章 の画像・印刷では, 磁気, 光磁気, フィルム, ハード
コピー，印刷の各分野にわたり，基礎技術を中心にま とめている.6 章の画像処理と合成では, コンピュー 夕による画像処理を数学的表現を多く用いて, 最近の 進歩について述べている.7 章の画像表示では, 数々 のハードウェアとシステムについて著しい発展をとげ ている分野に焦点をあて，解説している.

以上が基本技術に関する部分で, 以下の章は具体的 技術システムである.8 章の画像情報システムでは, 最近開発中のニューメディアを中心に具体的画像シス テムの形態や応用などについて述べ, 9 章の画像記 録・印刷システムでは, ソフトコピーとハードコピー に大別して新しい進歩を概説している．10 章の画像 処理・合成・認識システムでは, CT, CG, 文字・画 像, ロボットなどについて, 具体的システム例につい て最近の進歩を述べている.

以上のように本書は, 画像工学の領域を幅広くとら え, どちらかと言えば材料・デバイスよりは装置やシ ステムに重点をおいている。とくに最近の発展の著し い分野について, 基本的共通技術を重点に解説してい る、筆者は何れも長年にわたるその道の研究の第一人 者達である。

学生の参考書としてはもちろんのこと, 研究者, シ ステムエンジニアの座右の一冊としてぜひおすすめし たい.

\section{紹介 伊藤 豊（東京放送）}

朝倉書店刊（昭和 61 年 5 月発行）, A 5 判, 576 頁, 定価 12,000 円 